\title{
PELATIHAN KEWIRAUSAHAAN SEBAGAI UPAYA ANTISIPATIF DAMPAK PERKEMBANGAN INDUSTRI DI KECAMATAN KASOKANDEL
}

\author{
Melia Wida Rahmayani, Mochamad Febri, Nita Henita, \\ Wulan Riyadi, Yogi Ginanjar
}

Universitas Majalengka

meliawidar@unma.ac.id

\begin{abstract}
Job opportunities in Majalengka were increasingly after the establishment of many factories in manufacturing industries. Several business opportunities will grow include banking services, trade services, housing, food and many others in Kasokandel. Beside of positive impacts, there were also negative impacts felt by the community around the environment, namely an increase in factory waste pollution from the industry and the occurrence of disturbances and security. With this activity, Kasokandel community understands more about the current impacts, so that people were expected to be able to take advantage of good opportunities as a means of improving the standard of living of the community itself through community entrepreneurial development. The purpose of this training and mentoring activity was to increase entrepreneurial interest in the Kasokandel. The methods used in this activity were lectures, discussions and training supplies. The result of this activity was that the participants were more motivated to become creative and innovative entrepreneurs.
\end{abstract}

Keywords: Entrepreunership Training; Creative; Inovative; Kasokandel District;

\begin{abstract}
Abstrak
Peluang kerja di Kabupaten Majalengka semakin terbuka luas setelah banyak berdirinya sejumlah pabrik atau industri manufaktur. Beberapa peluang usaha yang akan tumbuh diantaranya, yaitu jasa perbankan, jasa perdagangan, perumahan, makanan dan lain-lain di Kecamatan Kasokandel. Selain dampak positif, ada juga dampak negatif yang dirasakan oleh pihak masyarakat sekitar lingkungan yaitu bertambahnya pencemaran limbah pabrik dari industri tersebut dan terjadinya gangguan ketertiban dan keamanan. Dengan adanya kegiatan ini masyarakat Kasokandel lebih memahami dampak yang terjadi saat ini, sehingga masyarakat diharapkan mampu memanfaatkan peluang baik sebagai sarana untuk meningkatkan taraf hidup masyarakat itu sendiri melalui pengembangan kewirausahaan masyarakat. Tujuan dari kegiatan pelatihan dan pendampingan ini adalah untuk meningkatkan minat kewirausahaan di masyarakat kecamatan Kasokandel. Metode yang digunakan dalam kegiatan ini adalah ceramah, diskusi dan pembekalan pelatihan. Hasil dari kegiatan ini peserta lebih termotivasi untuk menjadi wirausahawan yang kreatif dan inovatif.
\end{abstract}

Kata Kunci: Pelatihan Kewirausahaan; Kreatif; Inovatif; Kecamatan Kasokandel

Submitted: $2020-08-08$

Revised: 2020-09-25

Accepted: $2020-09-28$

\section{Pendahuluan}

Jawa Barat merupakan salah satu daerah dengan pertumbuhan ekonomi berbasis industri dengan kontribusinya mendekati 40\%. Kalau dikembangkan di koridor timur, potensi pembangunannya bisa ditingkatkan. Selama ini Jawa Barat berkontribusi besar terhadap pertumbuhan ekonomi daerah maupun nasional. Dalam hal ini, sumbangsih utamanya dari aktivitas industrialisasi, baik itu adanya peningkatan pada nilai investasi, penyerapan tenaga kerja, maupun capaian ekspor, sehingga Pemerintah berupaya menciptakan iklim bisnis yang kondusif serta memberikan insentif dan kemudahan 
perizinan usaha. Jawa Barat dinilai memiliki potensi besar pengembangan kawasan industri baru, terutama di bagian timur yang meliputi wilayah Majalengka, Cirebon, dan Subang. Menteri Perindustrian Airlangga Hartarto mengatakan kawasan tersebut disebut Segitiga Rebana. Peluang tersebut muncul karena ketersediaan infrastruktur yang strategis, yaitu Bandara Internasional Jawa Barat (BIJB) di Kertajati Majalengka, Pelabuhan Cirebon, dan Pelabuhan Patimban di Subang (Annisa, 2017).

Bandara Kertajati yang terletak di Majalengka, Jawa Barat tak hanya difungsikan sebagai Bandara Internasional saja, namun memiliki konsep Aerotropolis yang diharapkan bisa menyerap tenaga kerja di lingkungan sekitarnya. Deny Juanda, Kepala Badan Perencanaan Pembangunan Daerah (Bappeda) Jawa Barat mengungkapkan, selama ini di Majalengka dikenal memiliki penghasilan dari sektor agraris. Dengan adanya bandara ini, diharapkan Jawa Barat berkembang menjadi kawasan industri. "Kementerian Perindustrian menyebutkan 60\% industri di Cikarang, Jawa Barat. Cikarang itu ada di sisi barat, sedangkan Majalengka ada di sisi timurnya. Nantinya akan ada kembar kawasan industri," ujar Deny acara seminar The Future Plan and Design for Airport City \& Aerotropolis di Hotel Pullman, Kamis (13/02/2020). Deny menuturkan, pengembangan kawasan industri tersebut terkait dengan janji Pemerintah Jawa Barat yang menargetkan menyerap tenaga kerja besar. Kawasan industri di Cikarang merupakan kawasan industri berteknologi tinggi, namun tidak bisa terlalu banyak menyerap tenaga kerja, sedangkan di Majalengka nantinya akan dibuat kawasan industri berteknologi tinggi dengan melibatkan banyak pekerja (Riski, 2014).

Maka dari itu masyarakat Majalengka tak perlu alergi dengan pengembangan industri. Di kawasan Aerotropolis nantinya tak hanya berdiri pabrik produksi, tetapi akan ada untuk pengembangan produk atau riset. Ini sejalan dengan konsep Aerotropolis yang menjadikan bandara dan kota sebagai suatu kesatuan. Ketua Himpunan Kawasan Industri (HKI) Indonesia, Sanny Iskandar menuturkan kawasan industri Jawa Barat masih menjadi incaran bagi para investor untuk membangun pabrik. Bahkan, dijadikan sebagai basis produksi dan rantai pasoknya pasar global (Henri, 2019).

Kawasan industri Jawa Barat bagian timur dipandang kian menjanjikan. Hal ini sejalan dengan upaya pemerintah memacu pembangunan infrastruktur terintegrasi untuk pemerataan pertumbuhan ekonomi. Pengembangan dan pembangunan kawasan industri di Jawa Barat yang selama ini dipusatkan di bagian barat dan utara seperti Bekasi, Karawang, Purwakarta (Bekapur), mulai bergeser ke arah timur seperti Subang, Majalengka dan Cirebon. Kementerian Perindustrian menyiapkan tiga daerah untuk pemindahan (relokasi) industri padat karya. Iklim usaha industri ini terganggu oleh banjir dan kenaikan upah minimum di wilayah Jakarta. Khusus Majalengka, kawasan akan diubah menjadi pusat industri tekstil. Hal ini didasari melimpahnya sumber air bersih yang dimiliki kawasan tersebut. Ada 500 hektare lahan di Majalengka akan digunakan sebagai pabrik tekstil (tempo.co.id 2019).

Kabupaten Majalengka berpotensi menjadi kawasan industri tekstil baru di Jawa Barat. Direktur Jenderal Pengembangan Perwilayahan Industri Kementerian Perindustrian (Kemenperin) Imam Haryono mengatakan, pengembangan industri Jawa Barat masih memungkinkan, terutama di wilayah Timur. "Khususnya, di Kabupaten Majalengka berpotensi menjadi kawasan industri tekstil". Kawasan Majalengka menjadi relokasi 
sejumlah industri tekstil yang ada di kawasan Bandung Raya. Kawasan Majalengka memiliki hamparan datar yang ideal untuk industri. Selain itu, lokasinya juga berdekatan dengan BIJB. Kawasan baru ini juga akan terkoneksi dengan Tol Cileunyi- SumedangDawuan (harianjurnalasia, 2015).

Menteri Perindustrian Saleh Husin menargetkan penumbuhan populasi industri sebesar 9.000 ribu usaha industri berskala besar dan sedang serta 20.000 unit industri kecil. Sebanyak 50\% diantaranya ditargetkan tumbuh di luar Jawa. Menurut Ketua Apindo Jawa Barat Deddy Wijaya, pengembangan kawasan industri baru idealnya dilakukan kesiapan infrastruktur pendukungnya. Menurutnya, investor masih tertarik di Indonesia, termasuk Jawa Barat. Namun, harus didukung percepatan pembangunan infrastruktur seperti jalan tol dan bandara. Selain itu, biaya operasional industri saat ini cukup tinggi di semua sektor, baik dari transportasi, upah kerja dan biaya lainnya. Salah satunya akibat infrastruktur yang kurang mendukung. Dengan adanya industri baru, diharapkan pertumbuhan ekonomi di Jawa Barat dapat meningkat. Selain itu, industri baru ini diharapkan dapat menyerap lebih banyak tenaga kerja. Terus berdatangannya perusahaan tekstil dan garmen ke Kabupaten Majalengka membuat beberapa perusahaan tersebut membutuhkan ribuan tenaga kerja di Majalengka. Menurut Ketua Asosiasi Pertekstilan bahwa Majalengka diproyeksikan akan menjadi model kawasan Industri Tekstil (tempo.co.id 2019).

Jabargarmindo, PT. Gistex, dan PT. Listex membutuhkan sebanyak 12.000 tenaga kerja di Kabupaten Majalengka. Ini merupakan peluang bagi para pencari lowongan kerja di Majalengka. Berdatangannya industri tekstil ke Majalengka ini menjadi peluang bagi para pencari kerja dan memang pemerintah telah menyiapkan sekitar 3.500 hektar pembebasan lahan untuk kawan industri di Majalengka dengan mengorbankan lahan pertanian yang menjadi mata pencaharian masyarakat setempat salah satunya di Kecamatan Kasokandel (Yatna, 2014).

Peluang kerja di Kabupaten Majalengka semakin terbuka luas setelah banyak berdirinya sejumlah pabrik atau industri manufaktur. Berdasarkan data yang ada di Badan Pelayanan Perizinan Terpadu dan Penanaman Modal (BPPTPM), pada tahun 2015 pemerintah telah mengeluarkan 15 surat perizinan perusahanan besar yang tersebar di lima kecamatan yakni Kecamatan Kertajati, Jatiwangi, Kasokandel, Dawuan dan Sumberjaya. Tahun ini tidak menutup kemungkinan jumlah perusahaan besar akan terus bertambah, mengingat saat ini BPPTPM sudah menerima permohonan perizinan dari 12 perusahan besar lainnya masih dalam tahap pengkajian. Kepala BPPTPM H. Maman Faturochman melalui Kepala Bidang Perizinan Agus Suratman menjelaskan, dalam upaya memberikan kesempatan kerja kepada warga Majalengka pihaknya mewakili pemerintah daerah telah menjalin kontrak agar ke 15 perusahan atau pabrik tersebut mempekerjakan warga Majalengka. Berdasarkan hasil pantauannya ke sejumlah pabrik ditemukan adanya pekerja dari luar Kabupaten Majalengka, diakui pihak pabrik masih kekurangan tenaga kerja sehingga harus mengambil pekerja dari luar daerah. Setelah melakukan sosialisasi ke sejumlah daerah di Majalengka pendaftar kerja tidak sesuai yang diharapkan sehingga pihak pabrik terpaksa mengambil tenaga kerja dari Kabupaten Kuningan dan lainnya (S04, 2016).

Melalui Menteri Tenaga Kerja Nomor 5 Tahun 1989, pemerintah telah mencoba berbagai cara untuk mencegah perusahaan yang masih bersikap nakal dalam 
mengeksploitasi buruh wanita. Tetapi karena sanksi yang diberikan relatif ringan yaitu ancaman denda hanya Rp. 100.000,- dan sanksi hukuman yang diancamkan hanya 3 bulan penjara, maka dapat diduga pihak perusahaan tidak merasa terbebani dan bukan menjadi persoalan yang serius, sehingga peraturan pemerintah tersebut tidak berjalan secara efektif.

Pembangunan kawasan industri mempertimbangkan aspek sosial, ekonomi dan lingkungan sehingga memberikan dampak positif bagi perkembangan daerah khususnya kemajuan secara ekonomi. Dampak positif yang bisa dirasakan masyarakat yaitu terbukanya ribuan kesempatan lapangan kerja karena berbagai jenis industri akan memerlukan tenaga kerja untuk menjalankan produksi barang-barang yang dibuat pabrik. Tumbuhnya berbagai peluang usaha baru baik yang terkait langsung maupun yang tidak terkait langsung dengan industri tersebut. Beberapa peluang usaha yang akan tumbuh diantaranya, yaitu jasa perbankan, jasa perdagangan, perumahan, makanan dan lain-lain di Kecamatan Kasokandel tersebut. Selain dampak positif tersebut adapun dampak negatif yang dirasakan oleh pihak masyarakat sekitar dari lingkungan yaitu bertambahnya pencemaran limbah pabrik dari industri tersebut dan terjadinya gangguan ketertiban dan keamanan.

Salah satunya adalah masyarakat Kecamatan Kasokandel yang merupakan bagian dari Kabupaten Majalengka wilayah utara. Berdasarkan perencanaan tata ruang kota, Kecamatan Kasokandel diperuntukan sebagai wilayah industri. Ketersediaan lahan yang luas dan kontur wilayah sangat mendukung untuk berdirinya pabrik di wilayah ini. Lokasi industri sangat strategis karena ditunjang dengan akses ke Bandara Internasional Jawa Barat, Jalan Tol Cipali dalam waktu dekat akan terselesaikannya Tol Cisumdawu dan Pelabuhan Cirebon. Sehingga saat ini banyak industri yang didirikan di wilayah tersebut. Berdirinya industri tersebut menyerap tenaga kerja baik lokal maupun luar wilayah Kabupaten Majalengka. Jumlah penduduk Kecamatan Kasokandel yaitu 47.203 jiwa dengan luas wilayahnya yaitu $31,61 \mathrm{~km}^{2}$ dengan 10 desa/kelurahan (BPS Kabupaten Majalengka, 2018).

Berdasarkan hasil pengamatan dan wawancara dengan penduduk Kecamatan Kasokandel, dapat ditarik kesimpulan bahwa masyarakat setempat perlu dibekali pengetahuan dan pelatihan yang terkait dengan pengembangan potensi masyarakat setempat. Mengingat semakin banyak pendatang di daerah tersebut maka kebutuhan akan jasa perbankan, jasa perdagangan, perumahan, makanan dan lain-lain akan meningkat. Ini merupakan peluang yang perlu disikapi dengan baik oleh masyarakat sekitar. Agar perkembangan industri di Kecamatan Kasokandel dapat menguntungkan berbagai elemen termasuk masyarakat setempat.

Beberapa metode yang akan dilakukan atas dasar permasalahan yang muncul yaitu dengan cara pemberian pengetahuan dan pelatihan kepada masyarakat di Kecamatan Kasokandel khususnya terkait kewirausahaan. Oleh karena itu tim PKM akan mengangkat tema Pengabdian Kepada Masyarakat dengan judul "Pelatihan Kewirausahaan Sebagai Upaya Antisipatif Dampak Perkembangan Industri di Kecamatan Kasokandel". Tujuan dari pengabdian kepada masyarakat ini yaitu agar masyarakat Kasokandel lebih memahami dampak yang terjadi saat ini dan kedepannya, sehingga masyarakat diharapkan mampu 
memanfaatkan peluang baik ini sebagai sarana untuk meningkatkan taraf hidup masyarakat itu sendiri melalui pengembangan kewirausahaan masyarakat.

\section{Metode}

Kegiatan pengabdian kepada masyarakat menggunakan berbagai metode agar tepat sasaran. Alur pertama tim PKM yaitu melakukan komunikasi dan koordinasi dengan pihak Kecamatan Kasokandel untuk memperoleh data tentang jumlah peserta yang akan mengikuti kegiatan ini. Sehingga jadwal, tempat dan pola pelatihan serta pendampingan dapat disesuaikan dengan jumlah peserta. Sasaran peserta pada kegiatan PKM ini yaitu masyarakat yang masih produktif kisaran 20 - 40 Tahun. Karena tema yang diambil yaitu tentang "Pelatihan Kewirausahaan Sebagai Upaya Antisipatif Dampak Perkembangan Industri di Kecamatan Kasokandel". Masyarakat setempat harus cepat tanggap menghadapi perkembangan industri, melihat peluang bukan hanya menjadi buruh pabrik tapi mampu berwirausaha.

Pelatihan serta pendampingan tentang kewirausahaan dilaksanakan 4 (empat) kali pertemuan. Materi yang disampaikan akan dijelaskan sebagai berikut:

1) Penjelasan tentang minat wirausaha di masyarakat yang akan disampaikan oleh Yogi Ginanjar, S.E., M.Ak., Ak., CPA. Metode yang disampaikan berupa ceramah dan diskusi sehingga adanya umpan balik terhadap peserta.

2) Penjelasan tentang inovasi produk yang akan di sampaikan oleh Melia Wida Rahmayani, S.E., M.Ak. Metode yang disampaikan berupa ceramah, diskusi dan pendampingan membuat contoh produk.

3) Penjelasan tentang Packaging yang akan disampaikan oleh Moch. Febri Sayidil Umam, S.E., M.Ak. Metode yang disampaikan berupa ceramah dan membuka forum diskusi dengan peserta membawa peralatan pengemas produk.

4) Penjelasan tentang promosi serta marketing mix yang akan disampaikan oleh Nita Hernita, S.E., M.M., dan Wulan Riyadi S.E., M.Ak. Metode yang disampaikan berupa ceramah, diskusi serta penyampaian business plan dari perwakilan peserta.

Setelah kegiatan ini dilakukan, tim PKM akan melakukan evaluasi sejauh mana dampak perubahan yang terjadi di masyarakat akan antusiasme berwirausaha. Dengan cara melakukan survey data ke Desa-Desa yang ada di Kecamatan Kasokandel.

\section{Hasil dan Pembahasan}

Kecamatan Kasokandel Kabupaten Majalengka merupakan salah satu wilayah di Jawa Barat yang memiliki potensi industri yang tinggi. Pembangunan industri yang pesat di Kabupaten Majalengka ini memberikan dampak di bidang sosial maupun ekonomi. Keberadaan industri di wilayah tersebut memberikan kegelisahan tersendiri untuk masyarakat, terutama mendorong para pelaku usaha kecil dan menengah (UKM) untuk membuka peluang usaha baru dan mengembangkan yang ada di Kecamatan Kasokandel ini. Berbagai permasalahan yang timbul memberikan pengaruh secara langsung kepada masyarakat sekitar. Menjawab permasalahan yang ditimbul Tim PKM dengan Mitra sepakat melaksanakan berbagai pelatihan yang dilakukan guna membantu masyarakat setempat untuk menumbuhkan minat wirausaha agar tidak tergerus oleh industri besar 
dan bisa bersaing dengan perkembangan industri saat ini. Gambar di bawah ini adalah pelatihan pertama yang tim PKM lakukan.

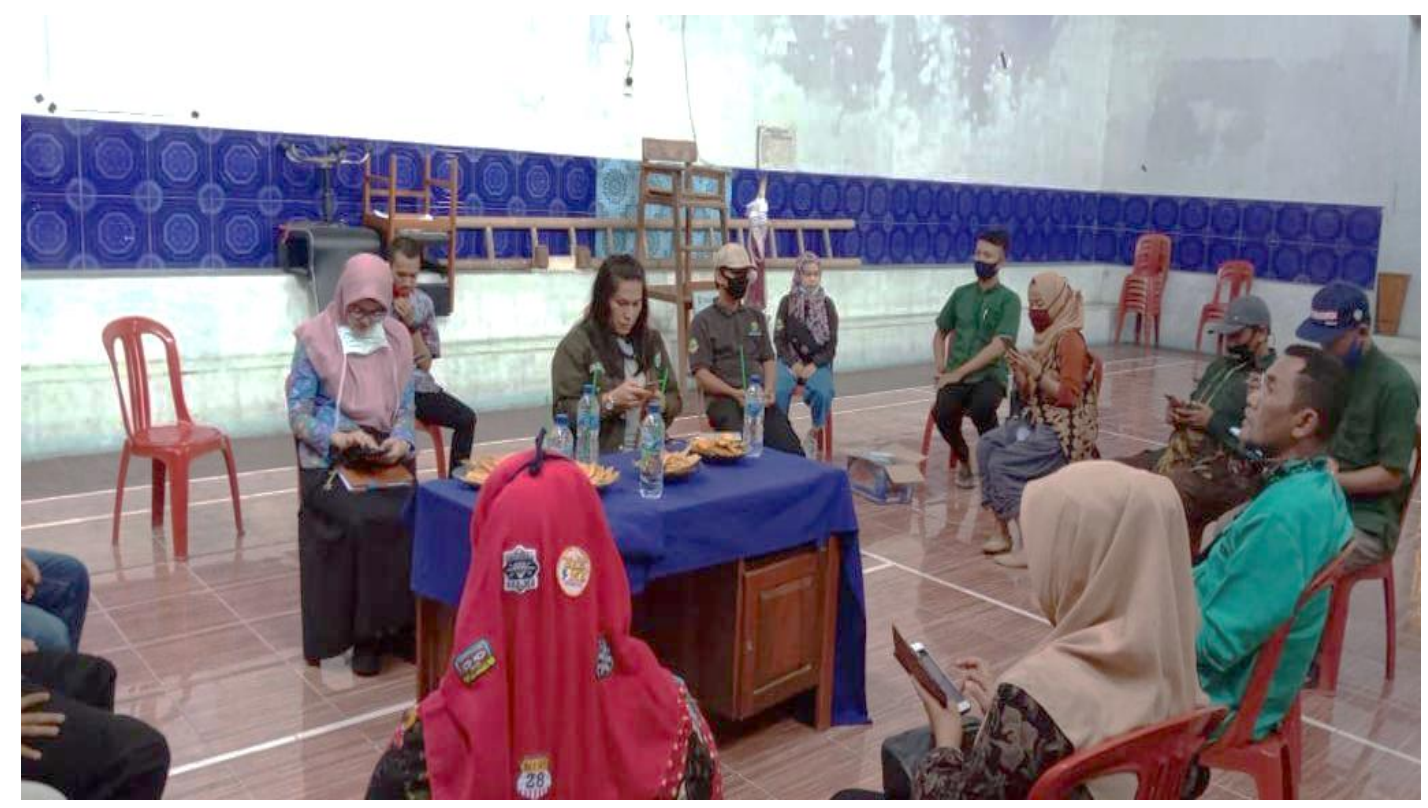

Gambar 1. Pelatihan Kewirausahaan

Pelatihan Kewirausahaan merupakan proses transformasi pengetahuan, sikap dan keterampilan dari sumber belajar kepada warga masyarakat. Tujuan pelatihan kewirausahaan ini adalah mampu memunculkan minat usaha kepada masyarakat. Mengingat lapangan kerja yang tersedia terbatas, namun perkembangan dunia wirausaha berdampak positif terhadap pengembangan daerah. Hal dibuktikan dengan banyaknya usaha kecil menengah yang mampu menyerap tenaga kerja. Selain itu dengan adanya pelatihan kewirausahaan mampu membentuk masyarakat menjadi lebih mandiri dan berani dalam mengambil keputusan serta mampu mempertimbangkan berdasarkan nilainilai ekonomis. Dalam proses pelatihan kewirausahaan ini masyarakat memperoleh keterampilan lain berupa mampu melakukan inovasi produk, pengembangan produk. Disamping pelatihan kewirausahaan ini tim PKM memberikan pelatihan inovasi produk untuk menambah kekuatan masyarakat dalam berwirausaha.

Hal tersebut dapat tergambar dari antusias masyarakat Kasokandel dalam mengikuti pelatihan kewirausahaan ini maupun pelatihan-pelatihan berikutnya. Setelah kegiatan ini selesai banyak masyarakat yang berdiskusi mengenai jenis usaha yang akan mereka lakukan. Sehingga dapat disimpulkan bahwa banyak potensi masyarakat sekitar yang dapat digali menjadi wirausahawan. 


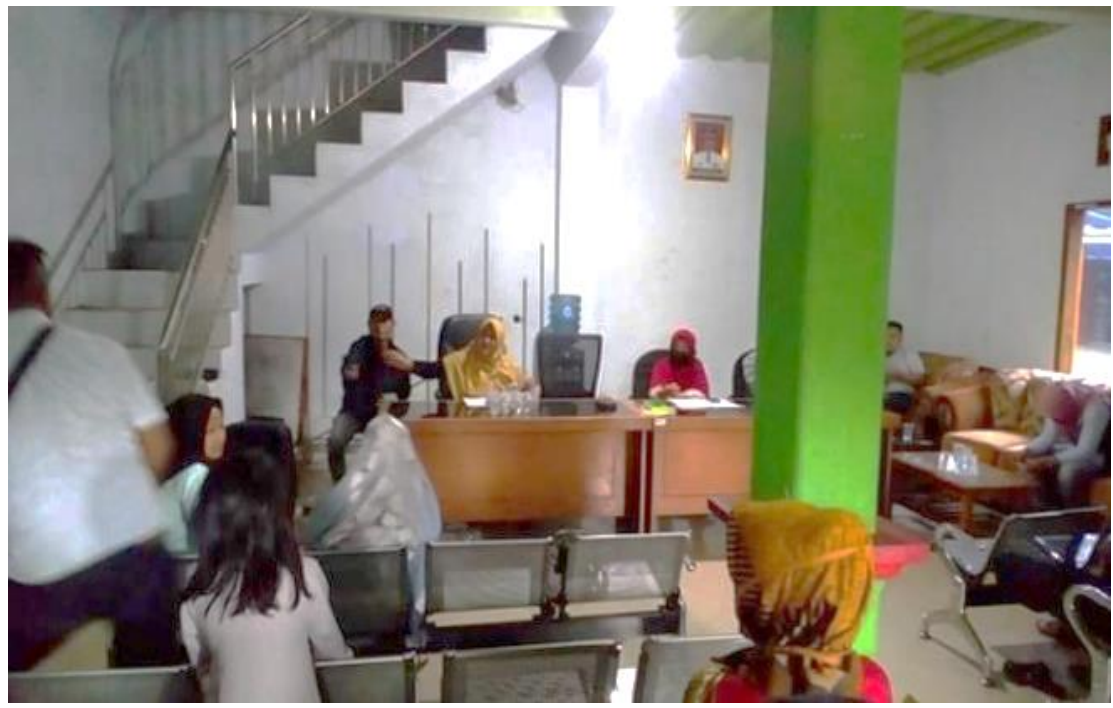

Gambar 2. Workshop Inovasi Produk

Inovasi adalah suatu proses pengembangan, pemanfaatan atau keterampilam dalam menghasilkan suatu produk. Suatu produk akan memiliki nilai lebih ketika produk tersebut melakukan inovasi yang di dukung oleh bisnis yang berkelanjutan. Setiap pelaku inovasi harus memiliki tiga kerangka kerja yakni, gagasan baru, bernilai dan model bisnis. Setiap inovasi bisa dipastikan merupakan sebuah gagasan baru yang kreatif. Gagasan ini diperoleh dari cara-cara yang tidak pernah dilakukan sebelumnya. Setiap inovasi bisa dipastikan memiliki nilai bagi pelanggan, jadi gagasan inovatif mampu memenuhi kebutuhan dan kepuasan pelanggan.

Berdasarkan hasil workshop inovasi produk banyak masyarakat yang menawarkan produk inovasi, baik dalam hal inovasi rasa, bentuk, kemasan maupun produk baru yang sebelumnya tidak diproduksi. Ini merupakan permulaan yang sangat baik dalam mengaplikasikan pelatihan berikutnya. Melengkapi kegiatan pelatihan yang dilakukan maka tim PKM melaksanakan pelatihan packaging guna mempercantik produk yang akan dihasilkan dan dijual serta menarik minat pembeli.

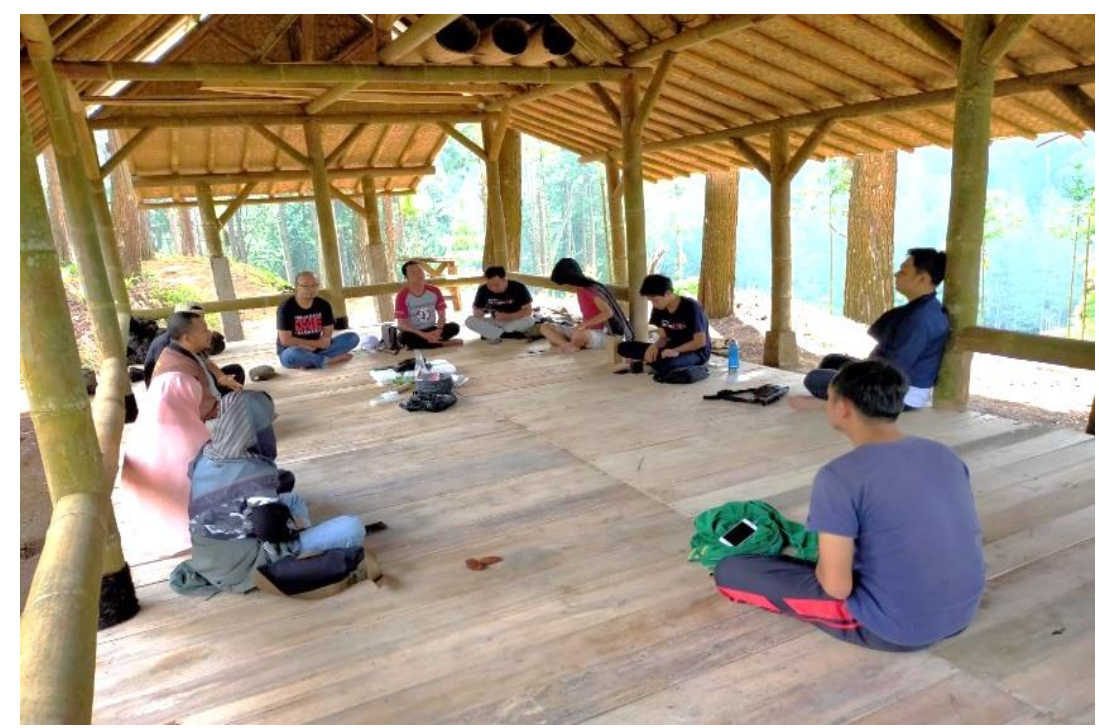

Gambar 3. Pelatihan Packaging 
Kegiatan TIM PKM yang dilakukan kepada masyarakat Kecamatan Kasokandel yang terdampak secara langsung dari pembangunan industri yang saat ini berkembang berupa pelatihan packaging. Melalui minat wirausaha dan inovasi produk masyarakat dibekali juga dengan pelatihan kemasan untuk mampu bersaing memasarkan produknya. Kemasan (packaging) adalah suatu hal yang sangat penting untuk dimiliki oleh setiap pebisnis ritel (bisnis penjualan barang). Ilmu mengenai packaging sendiri selalu berkembang dari masa-ke-masa. Dewasa ini, diperkenalkan suatu konsep baru yang dinamakan creative packaging. Dengan menggunakan creative packaging, seluruh potensi produk kita akan terpancar. Produk kita akan semakin mudah untuk dijual, pelanggan dapat langsung membayangkan produk yang akan dibelinya karena sudah tercermin dari kemasannya. Hal ini jelas memudahkan pelanggan dan meningkatkan pelanggan untuk membeli produk yang ditawarkan.

Berdasarkan hasil pelatihan packaging tim PKM menawarkan berbagai kemasan yang lebih menarik untuk produk-produk masyarakat Kasokandel. Salah satu contoh kemasan produk makanan ringan yang awalnya belum menggunakan stiker sekarang telah direkomendasikan oleh tim PKM untuk menggunakan stiker agar produk lebih menarik dan dikenal. Disamping itu kegiatan promosi mendorong masyarakat untuk bisa memasarkan produknya ke luar wilayah. Maka tim sepakat melakukan kegiatan pelatihan promosi guna meningkatkan persaingan pasar.

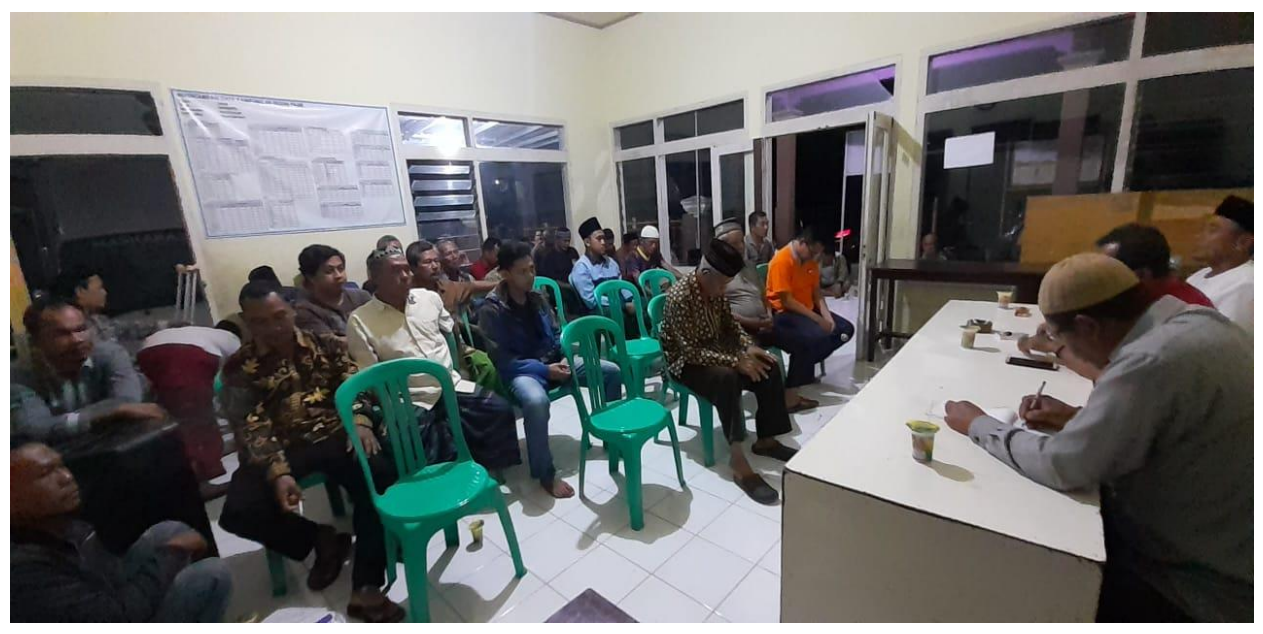

Gambar 4. Pelatihan Promosi

Perkembangan teknologi komunikasi saat ini memudahkan seseorang dalam melakukan berbagai kegiatan salah satunya pada bidang pemasaran. Untuk mengenalkan produk pada konsumen terdapat banyak cara seperti menggunakan media online (WA, Facebook, Instagram). Selain itu kami selaku TIM PKM mendorong masyarakat untuk memasarkan pula via e-commerce lain baik itu shopee, lazada, tokopedia dan lainnya. Melalui media online marketing produk mampu menjangkau konsumen yang ada di daerah-daerah, selain itu kita dapat mengefisiensikan waktu, tenaga, biaya dan modal serta dapat memperluas pasar.

Berdasarkan hasil pelatihan promosi maka tim PKM membantu mendampingi pembuatan media sosial dan cara penggunaannya agar masyarakat mampu melakukan kegiatan promosi secara digital. Mengingat saat ini ruang gerak masyarakat terbatas 
akibat adanya pandemi Covid-19. Sehingga pemasaran online sangat dibutuhkan di era revolusi industri 4.0 .

\section{Kesimpulan}

Kegiatan pelatihan dan pendampingan ini dilaksanakan 4 (empat) kali pertemuan. Materi yang disampaikan diantaranya yaitu penjelasan terhadap minat wirausaha, inovasi produk, packaging produk, dan marketing mix. Dengan kegiatan ini diharapkan masyarakat Kasokandel lebih memahami dampak yang terjadi saat ini dan kedepannya, sehingga masyarakat mampu memanfaatkan peluang baik ini sebagai sarana untuk meningkatkan taraf hidup masyarakat itu sendiri melalui pengembangan kewirausahaan masyarakat.

\section{Daftar Pustaka}

Annisa Sulistyo Rini. (2017). Pembangunan Kawasan Industri Baru Mengarah ke Jawa Barat. Bisnis.com. Diakses 06 September 2019

Arikunto, S. (2002). Prosedur Penelitian Sutau Pendekatan Praktek. Jakarta: Rineka Cipta.

Badan Pusat Statistik Kabupaten Majalengk. (2019). Jumlah penduduk dan Luas Wilayah Kecamatan Sumberjaya Kabupaten Majlengka.

Dinas Sosial Tenaga Kerja dan Transmigrasi. (2019). Lowongan Tenaga Kerja Kabupaten Majalengka. Diakses September 2019

Henri. (2019). Jawa Barat Perioritas Menjadi Kawasan Industri Baru Berita.id. Diakses 06 September 2019

https://issuu.com/harianjurnalasia/docs/01june2015

Ibrahim, R. (2007). IImu dan Aplikasi Pendidikan. Bandung: Imperial Bhakti Utama

NN. (2019). Tiga Kawasan Disiapkan untuk Relokasi Industri. Koran Tempo.co.id. Diakses 06 September 2019

Riski Widia Puspitasri. (2014). Kertajati bikin Majalengka jadi kawasan industri.Kontan.co.id. Diakses 05 September 2019

S04. (2016). Banyak Pabrik Berdiri Peluang Kerja di Majalengka Terbuka Luas.Sinar Media. Diakses September 2019

UU No.05. (1989). Menteri Tenaga Kerja. Diakses September 2019

Yatna Supriyatna. (2014). Majalengka didatangi 22 Perusahaan Tekstil dan Garmen. Bisnis.com. Bandung. Diakses 06 September 2019 